\title{
ASSESMENT OF ZINC CONTAMINATION IN THE SEDIMENT AND MANGROVE (AVICENNIA MARINA) AT WONOREJO MANGROVE, SURABAYA OF INDONESIA
}

\author{
Baihaqi Vanity Kurnia*, Yanuhar Uun \\ Department of Fisheries and Marine Science, University of Brawijaya, Malang, Indonesia \\ *E-mail: vanitykbaihaqi@gmail.com
}

\begin{abstract}
The existence of number industries in Surabaya as the largest industrial cities in Indonesia have affects how much waste they produce and is wasted in the waters. Heavy metal $\mathrm{Zn}$ (zinc) is one of the ingredients in the waste. The aim of this study was to analyze the $\mathrm{Zn}$ content in the roots and leaves of Avicennia marina as well as sediments around it which did in triplicates from 3 stations in Wonorejo Mangrove. The method used in this study was descriptive method. Zn analysis was used the Atomic Absorption Spectophotometer (AAS) method. Water quality analysis included temperature, $\mathrm{pH}$ and salinity was carried out in the field. The results of the $\mathrm{Zn}$ analysis obtained the highest value based on the station, namely at station 1 and the lowest at station 2. Based on the samples taken, the highest $\mathrm{Zn}$ concentration was found in the sediment and the lowest was in the leaves. The results of the concentration of $\mathrm{Zn}$ in the roots, leaves and sediment at each station did not differ much. The calculated values for BCF and TF were less than 1. Analysis of the water quality of the three parameters was still in normal conditions for the growth of mangrove biota. From this research, A. marina is included in the type of mangrove that can absorb heavy metals at low concentrations. This is in accordance with the BCF and TF values obtained. Low heavy metal absorption, this type of mangrove is still classified as a phytoremediator.
\end{abstract}

\section{KEY WORDS}

Avicennia marina, phytoremediator, heavy metal, water quality, bioconcentration factor, translocation factor.

The city of Surabaya is one of the big cities in Indonesia with a high number of industrial companies. According to [1] within 5 years the number of industries in the city of Surabaya continues to increase, where the increase is approximately $97 \%$. The number of industries in the city of Surabaya has had a bad impact on the waters. One of the causes of pollution in water areas is exposure to heavy metal concentrations. One type of heavy metal contained in water is zinc (Zn).

Overcoming pollution problems that occur in the waters of Surabaya can be done by phytoremediation through mangrove plants. According to [2] $\mathrm{Zn}$ is an essential micro nutrient that is useful for metabolic processes in plants. The Mangrove area in Wonorejo Surabaya is a forest area with an area of 200 hectares, in which there are more than 15 types of mangroves. A. marina or apis is a type of mangrove that has the ability to weaken toxic effects through a dilution process by storing excess water in its body tissues which is useful for diluting these toxic substances, for example heavy metals. Excessive $\mathrm{Zn}$ concentration in plants will have a negative impact, for example inhibiting plant metabolic processes, slowing growth and accelerating aging. Mangrove forest that has been planted on 200 hectares of land has its own role, one of which is maintaining the balance of the aquatic environmental ecosystem. $\mathrm{Zn}$ absorbed in the body of mangrove plants has a certain range to support the growth process, if the $\mathrm{Zn}$ concentration is very high it will inhibit the growth process. The process of $\mathrm{Zn}$ accumulation in mangrove roots and leaves as well as the surrounding sediment needs to be analyzed, to find out how much $\mathrm{Zn}$ concentration can be absorbed, whether this value exceeds the threshold or is in the normal range of $\mathrm{Zn}$ that accumulates in mangrove plants.

Based on the description above, it is necessary to conduct a research to be used as an environmental evaluation by controlling human activities around Wonorejo Mangrove Area, 
Surabaya, East Java, so that the existence of the resource is maintained from heavy metal pollution.

\section{METHODS OF RESEARCH}

The method used in this experiment was survey method. The experiment complete with primer or secondary data. Primer data include field observation data. Field observation based on the samples taken from the roots, leaves and sediment surround of mangrove and then checked the number of zinc inside it. Secondary data include science journals and books. The relation between $\mathrm{Zn}$ in the environment and the number of $\mathrm{Zn}$ in the roots and leaves used BCF and TF formulas.

Sampling was carried out based on the spread of $A$. marina in the Wonorejo Mangrove Area at 3 stations. Station 1 is near the residential area, station 2 is near the ecotourism area and station 3 is at the estuary. The sampling technique of $A$. marina mangroves is by looking at the age of the mangroves. The sample selection technique for mangrove plants is by looking at the diameter of the mangrove trunk measuring more than $5 \mathrm{~cm}$. The size is related to the root system and the quality of the mangrove plant species. There are 2 parts of mangrove plants that will be analyzed for $\mathrm{Zn}$ content, namely the roots and leaves.

Root sampling technique by taking roots submerged in water. Roots were taken with a size of $\pm 10-20 \mathrm{~cm}$ from the root tip. The selected roots weigh as much as 500 grams each and washed roots are put into a plastic that has been labeled. Leaf sampling technique, by selecting dark green leaves with a size is $8 \mathrm{~cm}$. Take leaves \pm 10 leaves in one tree at each station. Each station was repeated 3 times.

In addition to root and leaf samples, sediment samples were also taken using a sickle tool. Sediment samples were taken from each type of mangrove at each mangrove sampling station. Sediment took approximately $1 \mathrm{gram}$. Sediment samples that have been taken are put into plastic that has been marked.

According to [3], the analysis of heavy metal $\mathrm{Zn}$ in root/leaf/sediment samples was carried out with a sample preparation of $1 \mathrm{gram}$. Mix the sample with $10 \mathrm{ml}$ of $\mathrm{HNO}_{3}, 10 \mathrm{ml}$ of distilled water and $10 \mathrm{ml}$ of $\mathrm{H}_{2} \mathrm{SO}_{4}$. The sample was heated at $200{ }^{\circ} \mathrm{C}$ for $2-3$ hours and left until the smoke in the sample disappeared within 24-28 hours. The sample is filtered and allowed to stand again until the smoke is completely gone. Samples were analyzed using the Atomic Absorption Spect ophotometer at a wavelength of $235.5 \mathrm{~nm}$ and the results were recorded in ppm units.

According to [4], temperature measurements in the waters are carried out using an $\mathrm{Hg}$ thermometer which is calibrated using distilled water and cleaned using a tissue or cloth. $\mathrm{Hg}$ Thermo thermometer put into the water until the entire body of the $\mathrm{Hg}$ thermometer goes into the water. Wait for 2-3 minutes and read the temperature value through the numbers on the edge of the $\mathrm{Hg}$ thermometer, without the $\mathrm{Hg}$ thermometer being lifted from the water.

According to [5], salinity measurement was carried out using a refractometer by means of a refractometer calibrated using distilled water and cleaned using a tissue in the same direction. The water sample is taken using a dropper and counted onto the surface of the refractometer prism. The surface of the refractometer prism is closed and the salinity value on the refractometer is seen by reading the number on the round end of the refractometer.

According to [6], the method of measuring $\mathrm{pH}$ is carried out using a $\mathrm{pH}$ meter, namely by pressing the on button on the $\mathrm{pH}$ meter and then calibrated using distilled water. The $\mathrm{pH}$ meter is immersed in the water and wait 1-2 minutes to get the results of the $\mathrm{pH}$ of the water. The $\mathrm{pH}$ value will appear on the $\mathrm{pH}$ meter.

Bioconcentration is the tendency of chemicals present in the waters to enter the bodies of organisms in these waters. According to [7] BCF was calculated to determine the phytoremediation potential. According to [8] the BCF value is classified into 3 , namely the value of $B C F<1$ is called an excluder, $B C F=1$ is classified as an indicator plant and $B C F>1$ is an accumulator. The higher the BCF value, the plant is able to accumulate heavy metals higher than the accumulation of heavy metals in the soil. The BCF formula can be calculated as below: 


$$
B C F=\frac{\text { Heavy metal in roots or leaves }}{\text { Heavy metal in sediment }}
$$

According to [9] the TF value was calculated to evaluate the phytoextraction potential of accumulator plants. According to [10] translocation factors can determine the status of plants including phytoextractors or phytostabilizers. Phytoextractor status occurs when the TF value is more than 1, where the plant is able to accumulate heavy metals in the leaves from soil and water. If the TF value is less than 1, the plant is included in the phytostabilizer status. The TF formula can be calculated as below:

$$
T F=\frac{\text { Heavy metal concentration in leaves }}{\text { Heavy metal concentration in roots }}
$$

\section{RESULTS AND DISCUSSION}

Results of $\mathrm{Zn}$ concentration from 3 stations have different value. The value concentration based on Figure 1 as below.

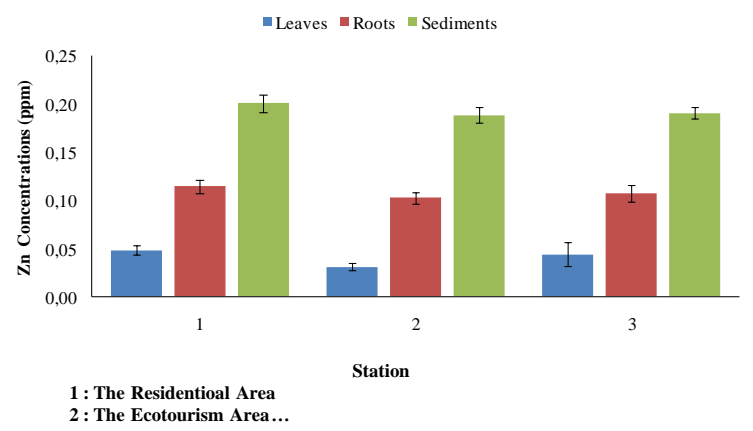

Figure 1 - Results of Zn Concentration in Roots and Leaves of $A$. marina and Sediment

Based on the sampling station, the $\mathrm{Zn}$ concentration in the roots and leaves of $A$. marina and the highest sediment was found at station 1 (near residential areas), with a $\mathrm{Zn}$ concentration value in leaves of $0.048 \mathrm{ppm}$, roots of $0.114 \mathrm{ppm}$ and sediment of $0.201 \mathrm{ppm}$ compared to station 2 (near ecotourism area) and station 3 (estuary).

Based on the sampling station, the $\mathrm{Zn}$ concentration in roots and leaves of $A$. marina and the highest sediment was found at station 1 (near residential areas), with a $\mathrm{Zn}$ concentration value in leaves of $0.048 \mathrm{ppm}$, roots of $0.114 \mathrm{ppm}$ and sediment of $0.201 \mathrm{ppm}$ compared to station 2 (near the area). ecotourism) and station 3 (estuary). The high value of $\mathrm{Zn}$ concentration in areas near settlements is mainly due to the amount of waste generated from household activities that directly enters the waters and accumulates in the mangroves. According to [12], the high concentration of $\mathrm{Zn}$ near settlements is also caused by industrial waste, hospitals, hotels and so on and flows into the residential area which is located adjacent to the mangrove area and then towards the estuary.

The lowest $\mathrm{Zn}$ concentration value was found at station 2, namely the Wonorejo mangrove ecotourism area. The concentration value on leaves was $0.03 \mathrm{ppm}$, roots were $0.103 \mathrm{ppm}$ and sediment was $0.188 \mathrm{ppm}$. According to [13] waste that has entered the mangrove area will be absorbed by mangrove plants. The nature of mangrove plants as absorbents of heavy metals, so as to reduce the concentration of heavy metals contained in the waste. According to [14], mangrove vegetation has the ability to adapt to extreme conditions, one of which is polluted environmental conditions.

The $\mathrm{Zn}$ concentration value based on the type of sample taken, the highest was found in the sediments around the mangroves. The sediment concentration values in the three ranged from $0.188-0.201 \mathrm{ppm}$. According to [15], the high value of $\mathrm{Zn}$ concentration in sediments is caused by the density of mangroves. According to [16], the condition of a dense 
root system in mangroves will reduce water movement so that very fine particles settle around the mangrove roots and form a collection of sediment layers.

The $\mathrm{Zn}$ concentration value in the leaves, where the value is the lowest compared to the mangrove roots and sediments around the mangrove. The $\mathrm{Zn}$ concentration value in the leaves ranges from $0.03-0.048 \mathrm{ppm}$. According to [16] the low concentration of $\mathrm{Zn}$ in the leaf organs is due to one of the reasons for the location of the leaves which do not interact directly with sediment, where sediment is the basis for the accumulation of heavy metals.

The mechanism of absorption of heavy metals is through the formation of chelates or phytosidorophores. Phytosodorophores formed will bind metals and carry them to root cells through an active transport process. The water-soluble compounds will be adsorbed on the roots along with the water, while the hydrophobic compounds will be absorbed by the root surface. According to [17], plant root cells generally contain ions with a higher concentration than the surrounding medium which is usually negatively charged. The absorption process in which cations enter the cell passively down an electrochemical gradient, while anions must be actively transported into plant root cells according to the state of the concentration gradient against the electrochemical gradient.

According to [18] the mechanism of plants exposed to toxic concentrations is to minimize the toxic effect (amelioration), localization that occurs in root organs, active excretion through glands in the canopy or passively through accumulation in old leaves followed by leaf shedding, dilution by attenuating the toxic concentration by dilution, chemical inactivation.

Table 1 - Results of BCF Roots and Leaves of A. marina

\begin{tabular}{lll}
\hline \multirow{2}{*}{ Station } & BCF & \\
& Roots & Leaves \\
\hline 1 & 0,56 & 0,24 \\
2 & 0,53 & 0,14 \\
3 & 0,51 & 0,29 \\
\hline
\end{tabular}

According to [19] a BCF value less than 1 was classified as an excluder. The value of BCF $<1$ indicates the low capacity of phytoextraction from vegetation so that metals are not transferred from the soil to the roots [20]. Phytoextraction efficiency depends on several factors, including the level of metal contamination, metal bioavailability, metal type, and the ability of vegetation to retain, absorb, and accumulate metals in vegetation tissue [21]. According to [22], the root BCF value was higher than the leaf BCF value, due to the position of the roots that interacted directly with the sediment. According to him, the accumulation of $\mathrm{Zn}$ in the part of the mangrove plant can decrease with the amount of water that is absorbed by the roots. The amount of water will dilute the $\mathrm{Zn}$ and the dilution takes place in the leaf tissue. The process of dilution of the leaves can cause thickening of the leaves. In addition to going through the dilution process, excretion is also possible to reduce the toxic substances present in mangrove plants. These toxic substances are mostly found in old leaves and stems that will peel off, so that the BCF in the leaves will be less than the BCF in the roots.

Table 2 - Results of TF Leaves of $A$. marina

\begin{tabular}{ll}
\hline Station & TF \\
\hline 1 & Leaves \\
2 & 0,43 \\
3 & 0,27 \\
\hline
\end{tabular}

According to [23], a TF value of less than 1 is classified as a phytostabilizer. According to [11] the TF value of $0.1-1$ includes a moderate accumulator. This moderate accumulator means that it indicates that the concentration of heavy metals from the roots to the shoots is in sufficient capacity. According to [16] the system of stopping heavy metals from the roots to the leaves occurs accumulation in roots. TF and or BCF values $<1$ indicate the occurrence of one of the vegetation defense mechanisms in adapting or responding to metal toxicity. 
The results of temperature measurements carried out at 3 stations obtained different values. Station 1 has a temperature value of $29 \stackrel{\circ}{ } \mathrm{C}$, station 2 has a temperature value of $28.8^{\circ} \mathrm{C}$. The temper ature value at the third station, which is at the estuary, obtained a temperature value of $29^{\circ} \mathrm{C}$. The results of temperature measurements at the three stations can be seen in Figure 2 below.

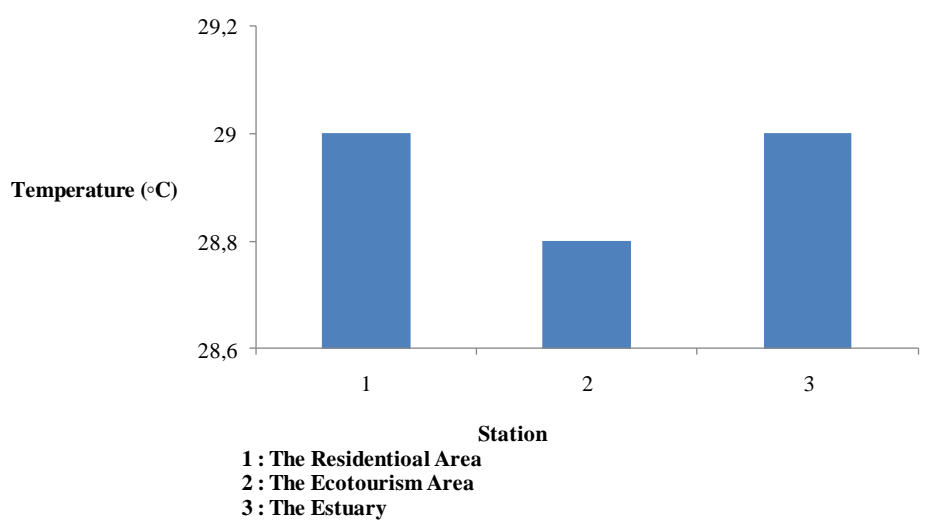

Figure 2 - Temperature Value at 3 Stations

According to [24] a good temperature range for the life of mangrove biota is $27-32^{\circ} \mathrm{C}$. The range value of the temperature measurements carried out at the three stations was $28.8-29^{\circ} \mathrm{C}$. This value is classified as normal condition which is in accordance with the quality standard based on the Decree of the Ministry of Environment No. 51 of 2004, where the temperature range is $28-32^{\circ} \mathrm{C}$. According to [25] the temperature value greatly affects the concentration of heavy metals in the waters. The high temperature value can cause high solubility of heavy metals so that the toxicity of these heavy metals is also high.

The results of $\mathrm{pH}$ measurements at the three measurement stations tend to be different values. The $\mathrm{pH}$ value at station 1 is 7.73 , at station 2 the $\mathrm{pH}$ value is 7.95 and at the third or last station the result is 8.18 . The average value of the three stations is 7.95 . The $\mathrm{pH}$ values at the three stations can be seen in Figure 3 below.

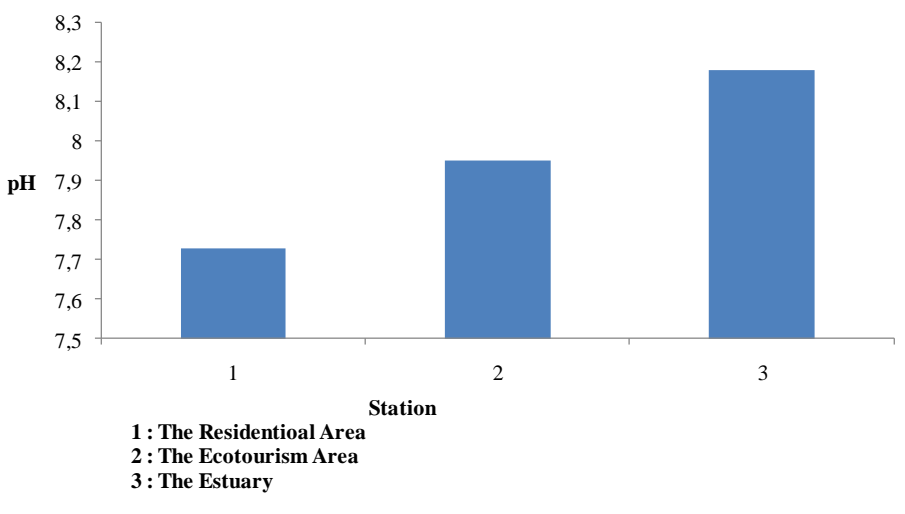

Figure 3 - Temperature Value at 3 Stations

The results of salinity measurements at 3 stations obtained different results. The salinity value at station 1 is $1 \mathrm{ppt}$, station 2 is $2 \mathrm{ppt}$ and station 3 is $3 \mathrm{ppt}$. The results of the salinity at the three stations can be seen in Figure 4 below. 


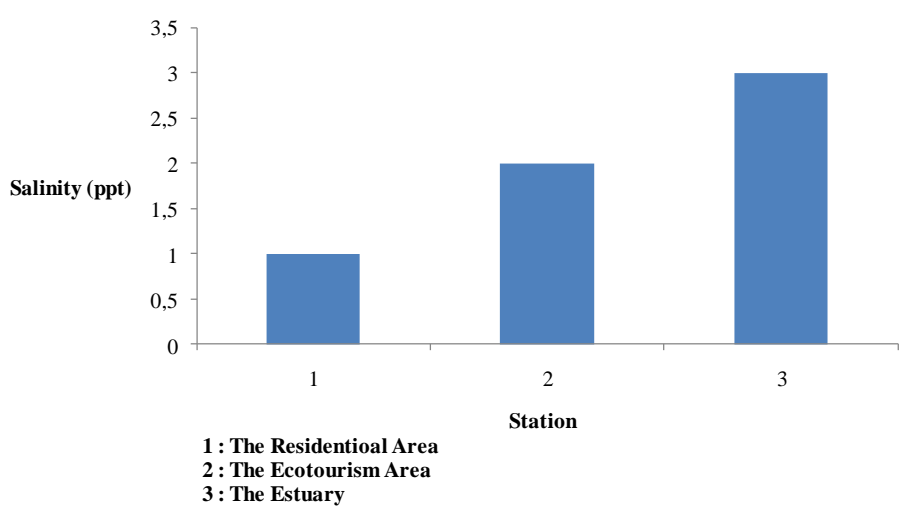

Figure 4 - Salinity Value at 3 Stations

The salinity values tend to be very small, ranging from 1-3 ppt. According to research [26] the salinity value for mangrove life is less than $33 \mathrm{ppt}$. The salinity value for mangrove biota according to the Ministry of Environment No. 51 of 2004 is up to a maximum limit of 34 ppt. The salinity value at the three stations increased as the station got closer to the ocean area. Station 1 has the smallest value because it is dominantly mixed with fresh water. Station 3 has the highest value where the river mouth is very close to the sea, so that the mixture with seawater is very dominant. The average salinity value of the three stations is 2 ppt. According to [27], one of the factors that influence the level of salinity is rainfall. High rainfall can cause low salinity values. The concentration of salinity also affects the concentration of heavy metals in the waters. High salinity means that the concentration of heavy metals in these waters is also high. Low concentrations of heavy metals and low salinity are caused by increased toxicity and accumulation of heavy metals.

\section{CONCLUSION}

The $\mathrm{Zn}$ concentration values in the roots and leaves of $A$. marina and the surrounding sediments did not differ significantly for each station. $A$. marina mangroves include mangroves that can absorb relatively low concentrations of $\mathrm{Zn}$ in the waters. The accumulated $\mathrm{Zn}$ concentration is quite low based on the BCF value of leaves and roots is $<1$ and the TF value of leaves is $<1$. Exposure to heavy metal $\mathrm{Zn}$ in $A$. marina can be said that this type of mangrove is classified as a phytoremediation plant, because it indirectly contains heavy metals in the soil and waters. will be reduced by the presence of $A$. marina.

\section{ACKNOWLEDGMENTS}

Thank you for the support from various parties in this research.

\section{CONFLICTS OF INTEREST}

The authors declare that this research does not have a conflict of interest with any party.

\section{REFERENCES}

1. Riyadi S. and S. Sumardi, "The Impact of Innovation Strategy toward Business Competitiveness of Manufacturing Industry in Surabaya, Indonesia," Hasanuddin Economics and Business Review, vol. 1, no. 1, 2017.

2. Krezel A. and W. Maret, " The biological inorganic chemistry of zinc ions," Arch Biochem Biophys, vol. 611, pp. 3-19, Dec 12016. 
3. Erakhrumen A. A., "Assessment of In-Situ Natural Dendroremediation Capability of Rhizophora racemosa in a Heavy Metal Polluted Mangrove Forest, Rivers State, Nigeria," Journal of Applied Sciences and Environmental Management, vol. 19, no. 1, 2015.

4. Ač A., Z. Malenovský, J. Olejníčková, A. Gallé, U. Rascher, and G. Mohammed, "Metaanalysis assessing potential of steady-state chlorophyll fluorescence for remote sensing detection of plant water, temperature and nitrogen stress," Remote Sensing of Environment, vol. 168, pp. 420-436, 2015.

5. Pozo M., F. Armijo, F. Maraver, J. M. Ejeda, and I. Corvillo, "Texture profile analysis (TPA) of clay/seawater mixtures useful for peloid preparation: Effects of clay concentration, pH and salinity," Applied Clay Science, vol. 165, pp. 40-51, 2018.

6. Sanlı A. E. and M. D. Mat, "Performance analysis of direct Black Sea hydrogen sulphide (in artificial sea water)/hydrogen peroxide fuel cells," International Journal of Hydrogen Energy, vol. 40, no. 19, pp. 6440-6448, 2015.

7. Rahman M. S. et al., "Source of metal contamination in sediment, their ecological risk, and phytoremediation ability of the studied mangrove plants in ship breaking area, Bangladesh," Mar Pollut Bull, vol. 141, pp. 137-146, Apr 2019.

8. Kaewtubtim P., W. Meeinkuirt, S. Seepom, and J. Pichtel, "Phytomanagement of radionuclides and heavy metals in mangrove sediments of Pattani Bay, Thailand using Avicennia marina and Pluchea indica," Mar Pollut Bull, vol. 127, pp. 320-333, Feb 2018.

9. Shi C., H. Ding, Q. Zan, and R. Li, "Spatial variation and ecological risk assessment of heavy metals in mangrove sediments across China," Mar Pollut Bull, vol. 143, pp. 115124, Jun 2019.

10. Abdullah E. L. M, R., M. Z. Rozainah, and N. K. Abu Bakar, "Evaluation of heavy metals and environmental risk assessment in the Mangrove Forest of Kuala Selangor estuary, Malaysia," Mar Pollut Bull, vol. 136, pp. 1-9, Nov 2018.

11. Li R., M. Chai, and G. Y. Qiu, "Distribution, Fraction, and Ecological Assessment of Heavy Metals in Sediment-Plant System in Mangrove Forest, South China Sea," PLoS One, vol. 11, no. 1, p. e0147308, 2016.

12. Aghamirlou H. M. et al., "Heavy metals determination in honey samples using inductively coupled plasma-optical emission spectrometry," J Environ Health Sci Eng, vol. 13, p. 39, 2015.

13. Almahasheer H., O. Serrano, C. M. Duarte, and X. Irigoien, "Remobilization of Heavy Metals by Mangrove Leaves," Frontiers in Marine Science, vol. 5, 2018.

14. Das S. K., J. K. Patra, and H. Thatoi, "Antioxidative response to abiotic and biotic stresses in mangrove plants: A review," International Review of Hydrobiology, vol. 101, no. 1-2, pp. 3-19, 2016.

15. Yang D., M. Wang, H. Lu, Z. Ding, J. Liu, and C. Yan, "Magnetic properties and correlation with heavy metals in mangrove sediments, the case study on the coast of Fujian, China," Mar Pollut Bull, vol. 146, pp. 865-873, Sep 2019.

16. Yan Z., X. Sun, Y. Xu, Q. Zhang, and X. Li, "Accumulation and Tolerance of Mangroves to Heavy Metals: a Review," Current Pollution Reports, vol. 3, no. 4, pp. 302-317, 2017.

17. Carvajal-Florez E. and C.-G. Santiago-Alonso, "Technologies applicable to the removal of heavy metals from landfill leachate," Environ Sci Pollut Res Int, vol. 26, no. 16, pp. 15725-15753, Jun 2019.

18. Analuddin K. et al., "Heavy metal bioaccumulation in mangrove ecosystem at the coral triangle ecoregion, Southeast Sulawesi, Indonesia," Mar Pollut Bull, vol. 125, no. 1-2, pp. 472-480, Dec 152017.

19. Buscaroli A., "An overview of indexes to evaluate terrestrial plants for phytoremediation purposes (Review)," Ecological Indicators, vol. 82, pp. 367-380, 2017.

20. Takarina N. D. and T. G. Pin, "Bioconcentration Factor (BCF) and Translocation Factor (TF) of Heavy Metals in Mangrove Trees of Blanakan Fish Farm," Makara Journal of Science, vol. 21, no. 2, 2017.

21. Midhat L., N. Ouazzani, M. Esshaimi, A. Ouhammou, and L. Mandi, "Assessment of heavy metals accumulation by spontaneous vegetation: Screening for new accumulator 
plant species grown in Kettara mine-Marrakech, Southern Morocco," Int J Phytoremediation, vol. 19, no. 2, pp. 191-198, Feb 2017.

22. Boim A. G., L. C. Melo, F. N. Moreno, and L. R. Alleoni, "Bioconcentration factors and the risk concentrations of potentially toxic elements in garden soils," J Environ Manage, vol. 170, pp. 21-7, Apr 12016.

23. Alzahrani D. A., E.-M. M. Selim, and M. M. El-Sherbiny, "Ecological assessment of heavy metals in the grey mangrove (Avicennia marina) and associated sediments along the Red Sea coast of Saudi Arabia," Oceanologia, vol. 60, no. 4, pp. 513-526, 2018.

24. Abdel-Halim A. M. and M. A. Aly-Eldeen, "Characteristics of Mediterranean Sea water in vicinity of Sidikerir Region, west of Alexandria, Egypt," The Egyptian Journal of Aquatic Research, vol. 42, no. 2, pp. 133-140, 2016.

25. Chen X.-G. et al., "Heavy metals from Kueishantao shallow-sea hydrothermal vents, offshore northeast Taiwan," Journal of Marine Systems, vol. 180, pp. 211-219, 2018.

26. Jaramillo F. et al., "Effects of Hydroclimatic Change and Rehabilitation Activities on Salinity and Mangroves in the Ciénaga Grande de Santa Marta, Colombia," Wetlands, vol. 38, no. 4, pp. 755-767, 2018.

27. Chen Y., Q. Xie, A. Sari, P. V. Brady, and A. Saeedi, "Oil/water/rock wettability: Influencing factors and implications for low salinity water flooding in carbonate reservoirs," Fuel, vol. 215, pp. 171-177, 2018. 